\title{
INVESTIGATING THE EFL TEACHERS ATTITUDES TOWARD THE INTEGRATION OF WEB 2.0 TOOLS IN TEACHING ENGLISH AT ISLAMIC BOARDING SCHOOLS
}

\author{
Helny Mullinda ${ }^{1} \&$ Supiani $^{2}$ \\ Universitas Islam Kalimantan MAB Banjarmasin, Indonesia \& \\ Mahasarakham University, Thailand \\ helny.suksesselalu@gmail.com \& supi_rus@yahoo.com
}

\begin{abstract}
The purposes of this study are to investigate EFL teachers' attitudes toward the integration of Web 2.0 tools in teaching English at Islamic Boarding Schools and to examine the extent of using Web 2.0 tools in teaching English at Islamic Boarding Schools. There were 18 EFL teachers from Islamic Boarding Schools in South Kalimantan province, Indonesia participated in this study. The data were taken from the EFL teachers were gathered by using the questionnaire, analyzed using descriptive statistics and followed up in the interview. The results of the study indicated that most EFL teachers have positive attitudes toward the integration of Web 2.0 tools in teaching English and percentages of their attitudes were high, with $75 \%$. The findings also showed that almost all of the EFL teachers strongly agreed that Web 2.0 tools made them more efficient and interesting in the teaching and learning process at the class. The majority of EFL teachers that integrated towards Web 2.0 tools in teaching English used tools such as YouTube, Google Sites, blogs, and wikis. However, there were the barriers that were faced by the EFL namely lack of technological equipment in school, limited time at the class to explore the technology and the students were not allowed to bring communication tools at the class, so Web 2.0 tools have not been fully explored at the English class.
\end{abstract}

Keywords: EFL teachers attitudes, The integration of Web 2.0 tools, Teaching English

\section{INTRODUCTION}

In Indonesia, English is as a foreign language taught widely both at formal and informal school, ranging from elementary school up to university. It becomes one of the compulsory subjects to be taught in the Junior High School and Senior High School and as local content in Elementary School. The Government paid considerable attention to this subject by including English in the curriculum to be implemented in the education system and as guidance for EFL teacher in teaching English at schools. Today English becomes an important language to be learned at school levels included an Islamic Boarding School.

Islamic Boarding School is the oldest Islamic educational institution in Indonesia that focuses on the mastery of the religious sciences by studying Islam from classical books. Islamic Boarding School is generally an informal school where students (called santri) who come from different or same areas learning to deepen the Islamic studies and sciences together (Haedar in Efrizal, 2012). In addition, to prioritize the knowledge of Islam, this educational institution also prioritizes the use of two foreign languages namely Arabic and English as a medium 


\section{Helny Mullinda*1 \& Supiani ${ }^{* 2}$ \\ INVESTIGATING THE EFL TEACHERS' ATTITUDES TOWARD THE INTEGRATION OF WEB 2.0 TOOLS IN TEACHING ENGLISH AT ISLAMIC \\ BOARDING SCHOOLS}

communication in teaching and learning activities. Indra (2017) stated that in this era, Pesantren as an institutional education is a part that could pay attention to it. Pesantren in the future should give knowledge to center dealt with broader perspectives in Islamic knowledge, as well as in science and technology, economic and also give attention to santri about entrepreneurship to enhance their skill of life and then could compete with others in this world.

In English teaching-learning process at Islamic Boarding Schools, a number of language teaching methods, techniques, and strategies are used by the teacher to awaken students' motivation to learn and also to enhance their English proficiency. Most of them apply the lecture method, frequently asked questions, eclectic, centralistic, transitional, and dual-language methods. Unfortunately, it's still taught conventionally through boring traditional methods that made learners don't interest during learning English and made the atmosphere in language class seem monotonous.

Meanwhile, the rapid development of information technology and the progress towards a digital world in education, have led to transform the roles of the $21^{\text {st }}$ century teachers and students from the previous century (Cirit, 2015). For this reason, teachers need to design, adapt and implement a curriculum that provides a technology-rich learning experience and authentic assessment to prepare learners to face the challenges of the $21^{\text {st }}$ century (Warner, Steffen, Amp Cope, 2011 in Cirit, 2015). With the rise of the networked technologies, especially Web 2.0 tools, pushes teachers to change their teaching and learning practices to support more interactive and innovative learning to provide meaningful and engaging learning experiences. The demands of technology to be used for teaching and learning have left teachers with no options but to integrate it into their teaching (Richardson, 2010).

Therefore, using Web 2.0 tools is a necessity to be integrated with teaching English. EFL Teachers need to make an environment that allows students to explore, learn more, and communicate better independently and in groups to improve their language proficiency. EFL Teachers need to exploit the integration of Web 2.0 tools in their English classes in a suitable way so that can make the teaching-learning process more innovative and more enjoyable. From the reasons above, the researcher is interested to investigate the EFL teachers' attitudes toward the integration of Web 2.0 tools in teaching English at Islamic Boarding Schools.

\section{LITERATURE REVIEW}

\section{Web 2.0 in English Language Teaching}

Web 2.0 is a web application offers two-way communication that allows interaction among users (McLeod and Vasinda, 2008, p. 260). It is available for users to enhance creativity, share and search for new information and answers to their questions by easier and to collaborate among them (Basal and Aytan, 2014, p. 372). The attendance of Web 2.0 technology as an Internet application platform that gives users the ability to actively create and distribute their content, enabling users to collaborate, interact socially, share information online, and gain knowledge (Grosseck, 2009). Web 2.0 is not only for browsing information but more emphasis 
on interaction among users. With the new technology of Web 2.0, users can easily post on blogs, create videos on YouTube, share posts on Google+, update their status on Facebook, tweet on Twitter, and other online activities.

In the field of $21^{\text {st }}$-century education, The Web 2.0 platform with their own unique potential has emerged in the world of communication and education (Julia, 2011), especially in teaching English such as blogs, podcasts, wikis, Edmodo, and Facebook. Web 2.0 tools have been integrated into the teaching and learning processes as innovative tools and approaches (Kassim \& Ali 2007) which are believed to influence students in increasing their interests and learning outcomes. Through the use of this application, students build their knowledge through social interaction, not just access the internet to simply get information. It is certainly very good at developing their language skill and ability, as they can interact and communicate online with users from different countries. Especially in improving the English acquisition, because generally the language used on Web 2.0 tools and online communication among users in English.

\section{Using Web 2.0 Tools in EFL Teaching}

Currently, the main purpose of teaching foreign languages is to expand learners own communicative competence in interacting with others using the target language by providing a learner-centered environment (Lee, 2005 in Ozel and Arikan, 2015). On the previous studies in EFL education have shown the main benefits of the used Web 2.0 technology in the classroom is to motivate students to improve their language proficiency (Lee, 2000 in Sulaiman, 2017), and encourage passive students to participate.

Web 2.0 tools have transformed EFL teaching by allowing both students and teachers to participate and interact in knowledge creation to build networks of learning (Kitsantas, 2013; Rosen, 2008 in Pradia, 2010). Access to Web 2.0 services is granted a long time in many ways. These services include widely spread applications like Facebook, Twitter, Google+, Flicker, Skype, and YouTube. These tools allow everyone who uses it to participate in building rich knowledge (Richardson, 2010).

Web 2.0 technology has taken the role in a part of daily life now (Greenhow, et al., 2009; Hsu \& Han, 2011; McBride, 2009; Richardson, 2010 in Keles, 2013), including in education. Web 2.0 Tools, creating a new methodology in EFL teaching that is friendly enough for teachers to augment their curriculum in a way that gives positive results and brings out the possibilities of unlimited digital technology that can be provided with respect to how students learn a foreign language. Most of these technologies offer several features that promote the use of Web 2.0 tools in various educational settings, despite they are not being designed for teaching and learning purposes (Ferdig, 2007 in Keles, 2013).

\section{English \\ 2. \\ . 7.027 \\ 527 \\ 270}

An attitude in simple can be interpreted as a condition for the emergence of action. Hogg and Vaughan (2005, p. 150) define an attitude as a feeling and behavioral tendency, in certain ways towards significant objects, groups, events or symbols in 


\section{Helny Mullinda ${ }^{* 1} \&$ Supiani $^{* 2}$ \\ INVESTIGATING THE EFL TEACHERS' ATTITUDES TOWARD THE INTEGRATION OF WEB 2.0 TOOLS IN TEACHING ENGLISH AT ISLAMIC BOARDING SCHOOLS}

social situations. Attitudes refer to individual evaluations of various aspects of the social world as well as how they evoke a sense of liking or disliking individuals towards issues, ideas, other people, social groups and objects (Baron, 2004: 39). In this study, attitude is focused on the attitudes of EFL teachers toward the integration of Web 2.0 tools.

Attitudes of EFL teachers play an important role when it comes to integrating technology in teaching English. As mentioned in Richards and Renandya (2002) in Sulaiman (2017) emphasized that the quality of the learning that takes place in the classroom is more determined by the teacher, not the technology. In addition, many researchers state that the most "decisive" factor in integrating and making the content and scope of use of technology in classrooms is teachers' attitudes regarding the role of technology (Sulaiman, 2017).

Teachers' attitudes both positive or negative are a major enable/disable factor in the integration of technology in teaching English (Bullock, 2004). Teachers' attitudes and beliefs may impede or support success the integration of technology such as Web 2.0 tools in an education program because teachers were perceived as very active agents with regard to the change process and implementing the new thoughts and ideas (Sulaiman, 2017). Gilakjani and Leong (2012) indicated that the success of students' learning with educational technology depends largely on the attitudes of EFL teachers, and their desire to adopt technology in the teaching process. EFL teachers' attitudes play an important related to their success in integrating and using technology in the classroom. Without considering teachers' attitudes, the function of Web 2.0 tools in teaching cannot be realized (Karkoulia, 2016).

Based on previous studies, most teachers have a positive attitude toward education technology (Spiris, 2014; Hadjirigas, 2012 in Karkoulia, 2016). Many of the extensive literature widely that explored on this subject has uncovered teachers' positive attitudes toward the use of technology in the classroom (in Albarini, 2004, Almekhlafi \& Almeqdadi, 2010; Ismail, Almekhlafi \& Almekhlafi, 2010 in Tanfouri, 2013) and in particular Web 2.0 tools (Crook et al., 2008 in Karkoulia, 2016). The findings of study conducted by Karkoulia (2016) to analysed the attitudes of the Greek teachers towards the integration of Web 2.0 tools in EFL teaching, to indicated which Web 2.0 tools were used by teachers, and to examine the challenges they face in integrating these tools in English class, demonstrated that the attitudes of the majority of EFL teachers were positive and that most of them used Web 2.0 tools like YouTube, Google Sites, blogs, and wikis. In another study, Ozel and Arikan (2015) explored the perception of EFL instructors in Turkish toward the use of Internet and Web 2.0 tools by them. The results showed that the EFL instructors did not use these tools regularly in EFL teaching even though they had positive attitudes toward them. Crook et al. (2008 in Karkoulia, 2016) found that $58.5 \%$ of teachers in the UK believe that popular Web 2.0 tools should be used more in the classroom. It means teachers have positive attitudes toward the use of Web 2.0 tools in the class. 


\section{RESEARCH METHOD}

This research used the descriptive quantitative method, particularly in the survey design. A survey is a research design that is generally used to gather information from a sample of the population of interest through questionnaires as the main data gathering tool. Surveys commonly consist of a set of questions or statements that explore things or characteristic of people such as demographics, attitudes, opinions, behaviors, perceptions, and beliefs (Chakravarty, 2013). One can describe the attitudes of the population from which the sample was drawn with a representative sample, that is, one which represents the whole of the larger population of interest (Kakkar, 2015). This research method was chosen by the researchers to investigate how the attitudes of the EFL teachers toward the integration of Web 2.0 tools in teaching English. The data for the study was taken from 19 EFL teachers at Islamic Boarding School, in South Kalimantan province, Indonesia participated in this study by random sampling technique using the questionnaire and followed up the interview. The research instrument applied in this study was a closed questionnaire with some open-ended questions for obtaining deeply information and used a Likert scale form. Likert scales are widely used to measure the attitude, opinion, or perception, someone. The questionnaire was distributed to the EFL teachers from a different Islamic boarding school in order to get information about how teachers' attitudes toward the integration of Web 2.0 tools in teaching English. The questionnaire was given to the teachers and filled by them based on their own feeling or opinion. A list of the questionnaire in the close-ended version was made with five options. In analyzing data, the researchers used the step as follows:

\section{Editing}

Editing was the process of checking and resolving data that has been obtained in the field, through questionnaires.

2. Coding

Coding was an attempt to classify respondents' answers by type of question by marking on each data falling into the same category.

3. Tabulation

Tabulation was the process of collecting data that has been obtained in the table with the aim to simplify the data with the process of calculating the frequency of each category, by manual or by using the computer. Each response was then associated with a particular point and every respondent's scores were then determined by summing up the points of each statement.

\section{FINDINGS AND DISCUSSION}

\section{Respondents $\quad 0 \quad 7$}

Based on 18 questionnaires that can be processed, obtained information about demographics of respondents as a reference in looking at the characteristics of respondents into a research sample. The description of the characteristics of respondents in this study based on gender, academic qualification, and teaching experience. In more detail the characteristics of respondents can be seen in the following table:

Table 1 Respondents' Background 
Helny Mullinda*1 \& Supiani ${ }^{* 2}$

INVESTIGATING THE EFL TEACHERS' ATTITUDES TOWARD THE INTEGRATION OF WEB 2.0 TOOLS IN TEACHING ENGLISH AT ISLAMIC

BOARDING SCHOOLS

\begin{tabular}{|c|c|c|c|c|}
\hline No. & Criteria of Respondents & Sub-criteria & Freq. & Percent \\
\hline 1. & Gender & $\begin{array}{l}\text { Male } \\
\text { Female }\end{array}$ & $\begin{array}{c}4 \\
14\end{array}$ & $\begin{array}{l}22.2 \% \\
77.8 \%\end{array}$ \\
\hline \multicolumn{3}{|c|}{ Total } & 18 & $100 \%$ \\
\hline 2. & Academic Qualification & $\begin{array}{l}\text { Diploma } \\
\text { Bachelor Degree } \\
\text { Master Degree } \\
\text { Other (Senior High School) }\end{array}$ & $\begin{array}{c}0 \\
15 \\
0 \\
3\end{array}$ & $\begin{array}{r}0 \\
83.3 \% \\
0 \\
16.7 \%\end{array}$ \\
\hline \multicolumn{3}{|c|}{ Total } & 18 & $100 \%$ \\
\hline 3. & Teaching Experience & $\begin{array}{l}\text { 1-5 Years } \\
6-10 \text { Years } \\
11-15 \text { Years } \\
16-20 \text { Years } \\
\text { 21-25 Years } \\
26+\text { Years }\end{array}$ & $\begin{array}{l}10 \\
5 \\
2 \\
1 \\
0 \\
0\end{array}$ & $\begin{array}{r}55.6 \% \\
27.8 \% \\
11 \% \\
5.6 \% \\
0 \\
0\end{array}$ \\
\hline \multicolumn{3}{|c|}{ Total } & 18 & $100 \%$ \\
\hline
\end{tabular}

Based on Table 4.1 no. 1 above shows that about $77.8 \%$ of respondents are dominated by females, and the rest is $22.2 \%$ of respondents of the males. Here is the diagram about gender:

Based on table 4.1 no. 2 can be seen that most respondents in the majority of research educated bachelor of degree $15 \mathrm{EFL}$ teachers or $83.3 \%$, and the remaining 3 EFL teachers or $16.7 \%$ graduated Senior High School.

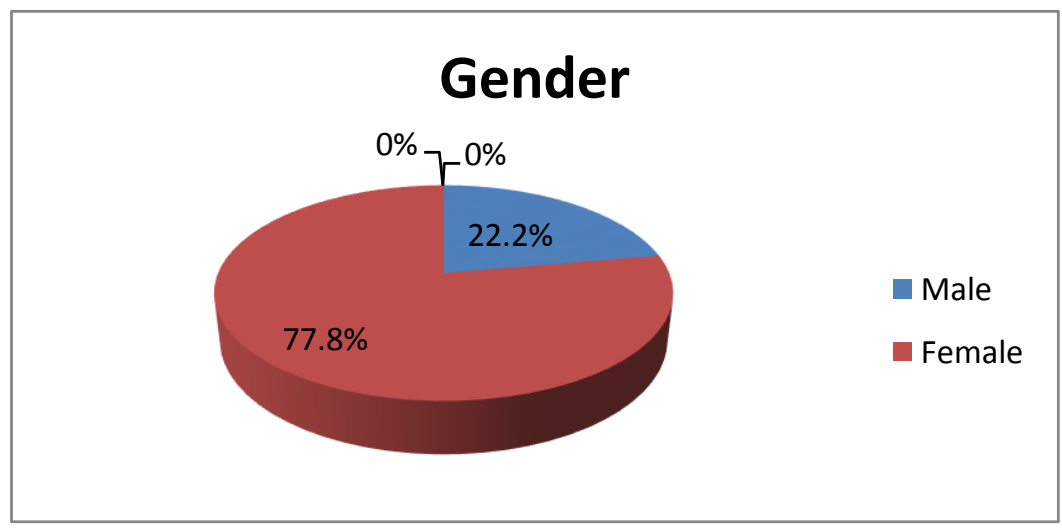




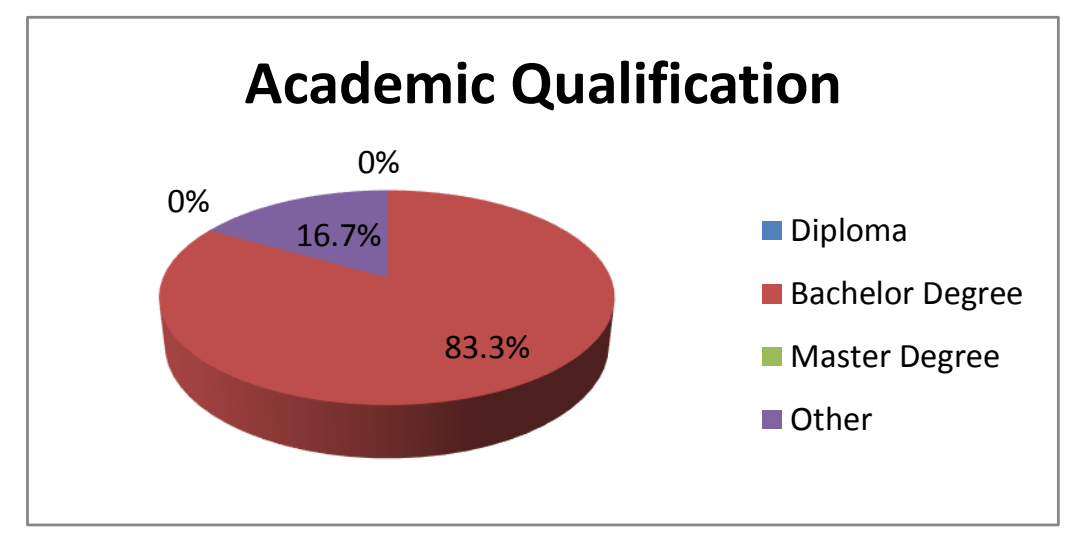

Based on table number 3 could be seen that most respondents that have been teaching for $1-5$ years as many 10 EFL teachers or by $55.5 \%$. Then $27.8 \%$ or as many as 5 EFL teachers have been teaching for 6-10 years, amounting to $11 \%$ or by 2 EFL teachers have taught for 11-15 years and 1 respondent has been teaching for 16-20 years.

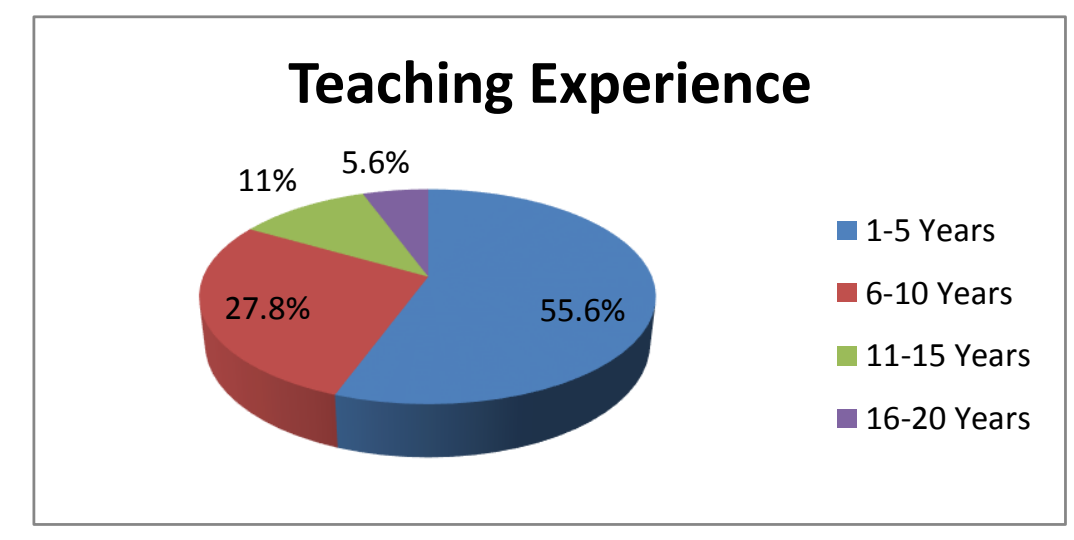

\section{English at Islamic Boarding Schools}

.7 .027

5 2n Teaching

In order to analyze the EFL teachers' attitudes toward the integration of Web 2.0 tools, descriptive statistics were calculated, including the frequency, percent, mean values and other categories for items of the questionnaire. The results of the data processor are presented in table 2. As the questionnaire was a blend of both positively and negatively items, the score of the negatively worded statements were reversed. It gave an overview of the results of the study, then determined the category of valuation based on scores obtained from the results of the questionnaire. 
Table 2. The Results Of Questionnaire Data Processing

\begin{tabular}{|c|c|c|c|c|c|c|c|c|c|c|c|c|c|c|}
\hline \multirow[b]{2}{*}{ No. } & \multirow[b]{2}{*}{ Statements } & \multicolumn{5}{|c|}{ Measurement Scale } & \multicolumn{5}{|c|}{ Weight } & \multirow[b]{2}{*}{$\sum$} & \multirow[b]{2}{*}{$\%$} & \multirow[b]{2}{*}{$\mathbf{M}$} \\
\hline & & $\begin{array}{c}\text { SA } \\
\mathbf{f} \\
\%\end{array}$ & $\begin{array}{c}\mathbf{A} \\
\mathbf{f} \\
\%\end{array}$ & $\begin{array}{c}\mathbf{N} \\
\mathbf{f} \\
\%\end{array}$ & $\begin{array}{c}\text { D } \\
\text { f } \\
\%\end{array}$ & $\begin{array}{c}\mathbf{f} \\
\%\end{array}$ & $\bar{y}$ & & 2 & $f$ & & & & \\
\hline 1. & $\begin{array}{l}\text { I like to use Web } 2.0 \\
\text { tools. }\end{array}$ & $\begin{array}{c}4 \\
22.2\end{array}$ & $\begin{array}{c}14 \\
77.8\end{array}$ & 0 & 0 & 0 & 5 & 4 & 3 & 2 & 1 & 76 & $\begin{array}{c}84 . \\
4\end{array}$ & $\begin{array}{c}4.2 \\
2\end{array}$ \\
\hline 2. & $\begin{array}{l}\text { I often use Web } 2.0 \\
\text { tools in teaching } \\
\text { English. }\end{array}$ & 0 & $\begin{array}{c}10 \\
55.6\end{array}$ & $\begin{array}{c}4 \\
22 . \\
2\end{array}$ & $\begin{array}{c}3 \\
16 . \\
7\end{array}$ & $\begin{array}{c}1 \\
5.6\end{array}$ & 5 & 4 & 3 & 2 & 1 & 59 & $\begin{array}{c}65 . \\
6\end{array}$ & $\begin{array}{c}3.2 \\
8\end{array}$ \\
\hline 3. & $\begin{array}{l}\text { Using Web } 2.0 \text { tools } \\
\text { make me more } \\
\text { efficient in teaching } \\
\text { English. }\end{array}$ & $\begin{array}{c}1 \\
5.6\end{array}$ & $\begin{array}{c}16 \\
88.9\end{array}$ & $\begin{array}{c}1 \\
5.6\end{array}$ & 0 & 0 & 5 & 4 & 3 & 2 & 1 & 72 & 80 & 4.0 \\
\hline 4. & $\begin{array}{l}\text { Using Web } 2.0 \text { tools } \\
\text { make my lessons } \\
\text { more interesting. }\end{array}$ & $\begin{array}{c}1 \\
5.6\end{array}$ & $\begin{array}{c}16 \\
88.9\end{array}$ & $\begin{array}{c}1 \\
5.6\end{array}$ & 0 & 0 & 5 & 4 & 3 & 2 & 1 & 72 & 80 & 4.0 \\
\hline 5. & $\begin{array}{l}\text { I like searching the } \\
\text { internet for teaching } \\
\text { resources. }\end{array}$ & $\begin{array}{c}4 \\
22.2\end{array}$ & $\begin{array}{c}14 \\
77.8\end{array}$ & 0 & 0 & 0 & 5 & 4 & 3 & 2 & 1 & 76 & $\begin{array}{c}84 . \\
4\end{array}$ & $\begin{array}{c}4.2 \\
2\end{array}$ \\
\hline 6. & $\begin{array}{l}\text { Using Web } 2.0 \text { tools } \\
\text { make me more } \\
\text { creative. }\end{array}$ & $\begin{array}{c}2 \\
11.1\end{array}$ & $\begin{array}{c}13 \\
72.2\end{array}$ & $\begin{array}{c}3 \\
16 . \\
7\end{array}$ & 0 & 0 & 5 & 4 & 3 & 2 & 1 & 71 & $\begin{array}{c}78 . \\
9\end{array}$ & $\begin{array}{c}3.9 \\
4\end{array}$ \\
\hline 7. & $\begin{array}{l}\text { The integration of } \\
\text { Web } 2.0 \text { tools is part } \\
\text { of the whole my } \\
\text { lesson in teaching } \\
\text { English. }\end{array}$ & 0 & $\begin{array}{c}11 \\
61.1\end{array}$ & $\begin{array}{c}4 \\
22 . \\
2\end{array}$ & $\begin{array}{c}3 \\
16 . \\
7\end{array}$ & 0 & 5 & 4 & 3 & 2 & 1 & 62 & $\begin{array}{c}68 . \\
9\end{array}$ & $\begin{array}{c}3.4 \\
4\end{array}$ \\
\hline 8. & $\begin{array}{l}\text { Web } 2.0 \text { tools make } \\
\text { my teaching task easy } \\
\text { in the classroom. }\end{array}$ & $\begin{array}{c}1 \\
5.6\end{array}$ & $\begin{array}{c}15 \\
83.3\end{array}$ & $\begin{array}{c}2 \\
11 . \\
1\end{array}$ & 0 & 0 & 5 & 4 & 3 & 2 & 1 & 71 & $\begin{array}{c}78 . \\
9\end{array}$ & $\begin{array}{c}3.9 \\
4\end{array}$ \\
\hline 9. & $\begin{array}{l}\text { Web } 2.0 \text { tools are an } \\
\text { efficient means for } \\
\text { obtaining } \\
\text { information. }\end{array}$ & $\begin{array}{c}3 \\
16.7\end{array}$ & $\begin{array}{c}14 \\
77.8\end{array}$ & $\begin{array}{c}1 \\
5.6\end{array}$ & 0 & 0 & 5 & 4 & 3 & 2 & 1 & 74 & $\begin{array}{c}82 . \\
2\end{array}$ & $\begin{array}{c}4.1 \\
1\end{array}$ \\
\hline 10. & $\begin{array}{l}\text { Web } 2.0 \text { tools fit well } \\
\text { to integrate into my } \\
\text { curriculum goals in } \\
\text { an English subject. }\end{array}$ & $\begin{array}{c}2 \\
11.1\end{array}$ & $\begin{array}{c}12 \\
66.7\end{array}$ & $\begin{array}{c}4 \\
22 . \\
2\end{array}$ & 0 & 0 & 5 & 4 & 3 & 2 & 1 & 70 & $\begin{array}{c}77 . \\
8\end{array}$ & $\begin{array}{c}3.8 \\
9\end{array}$ \\
\hline 11. & $\begin{array}{l}\text { I do not feel } \\
\text { comfortable when I } \\
\text { use Web } 2.0 \text { tools. }\end{array}$ & $\begin{array}{c}1 \\
5.6\end{array}$ & 0 & $\begin{array}{c}3 \\
16 . \\
7 \\
\end{array}$ & $\begin{array}{c}11 \\
61 . \\
1\end{array}$ & $\begin{array}{c}3 \\
16 . \\
7 \\
\end{array}$ & 1 & 2 & 3 & 4 & 5 & 69 & $\begin{array}{c}76 . \\
7\end{array}$ & $\begin{array}{c}3.8 \\
3\end{array}$ \\
\hline 12 . & $\begin{array}{l}\text { I think that class time } \\
\text { is too limited to } \\
\text { integrate Web } 2.0 \\
\text { tools in teaching } \\
\text { English. }\end{array}$ & $\begin{array}{c}3 \\
16.7\end{array}$ & $\begin{array}{c}9 \\
50.0\end{array}$ & $\begin{array}{c}3 \\
16 . \\
7\end{array}$ & $\begin{array}{c}3 \\
16 . \\
7\end{array}$ & 0 & 1 & 2 & 3 & 4 & 5 & 42 & $\begin{array}{c}46 . \\
6\end{array}$ & $\begin{array}{c}2.3 \\
3\end{array}$ \\
\hline 13. & $\begin{array}{l}\text { If I have access to the } \\
\text { resource, I would like } \\
\text { to try out Web } 2.0 \\
\text { tools innovations in } \\
\text { my teaching. }\end{array}$ & $\begin{array}{c}1 \\
5.6\end{array}$ & $\begin{array}{c}14 \\
77.8\end{array}$ & $\begin{array}{c}3 \\
16 . \\
7\end{array}$ & 0 & 0 & 5 & 4 & 3 & 2 & 1 & 70 & $\begin{array}{c}77 . \\
8\end{array}$ & $\begin{array}{c}3.8 \\
9\end{array}$ \\
\hline
\end{tabular}




\begin{tabular}{|c|c|c|c|c|c|c|c|c|c|c|c|c|c|c|}
\hline 14. & $\begin{array}{l}\text { Web } 2.0 \text { tools can be } \\
\text { a great supplement to } \\
\text { support teaching } \\
\text { English. }\end{array}$ & $\begin{array}{c}2 \\
11.1\end{array}$ & $\begin{array}{c}15 \\
83.3\end{array}$ & $\begin{array}{c}1 \\
5.6\end{array}$ & 0 & 0 & 5 & 4 & 3 & 2 & 1 & 73 & $\begin{array}{c}81 . \\
1\end{array}$ & $\begin{array}{c}4.0 \\
6\end{array}$ \\
\hline 15. & $\begin{array}{l}\text { I am not ready to } \\
\text { integrate Web } 2.0 \\
\text { tools in my teaching. }\end{array}$ & 0 & $\begin{array}{c}4 \\
22.2\end{array}$ & $\begin{array}{c}5 \\
27 . \\
8\end{array}$ & $\begin{array}{c}9 \\
50 . \\
0\end{array}$ & 0 & 1 & 2 & 3 & 4 & 5 & 59 & $\begin{array}{c}65 . \\
6\end{array}$ & $\begin{array}{c}3.2 \\
8\end{array}$ \\
\hline 16. & $\begin{array}{l}\text { I am hesitant to } \\
\text { integrate Web } 2.0 \\
\text { tools because I } \\
\text { believe that } \\
\text { traditional methods of } \\
\text { teaching English are } \\
\text { more effective. }\end{array}$ & 0 & $\begin{array}{c}2 \\
11.1\end{array}$ & $\begin{array}{c}5 \\
27 . \\
8\end{array}$ & $\begin{array}{c}10 \\
55 . \\
6\end{array}$ & $\begin{array}{c}1 \\
5.6\end{array}$ & 1 & 2 & 3 & 4 & 5 & 64 & $\begin{array}{c}71 . \\
1\end{array}$ & $\begin{array}{c}3.5 \\
6\end{array}$ \\
\hline 17. & $\begin{array}{l}\text { Web } 2.0 \text { tools } \\
\text { encourage students to } \\
\text { study more. }\end{array}$ & $\begin{array}{c}2 \\
11.1\end{array}$ & $\begin{array}{c}14 \\
77.8\end{array}$ & $\begin{array}{c}2 \\
11 . \\
1\end{array}$ & 0 & 0 & 5 & 4 & 3 & 2 & 1 & 72 & 80 & 4.0 \\
\hline 18. & $\begin{array}{l}\text { Working the English } \\
\text { tasks with the help of } \\
\text { Web } 2.0 \text { tools } \\
\text { motivates students. }\end{array}$ & 0 & $\begin{array}{c}16 \\
88.9\end{array}$ & $\begin{array}{c}2 \\
11 \\
1\end{array}$ & 0 & 0 & 5 & 4 & 3 & 2 & 1 & 70 & $\begin{array}{c}77 . \\
8\end{array}$ & $\begin{array}{c}3.8 \\
9\end{array}$ \\
\hline 19. & $\begin{array}{l}\text { Using Web } 2.0 \text { tools } \\
\text { distracts students. }\end{array}$ & 0 & $\begin{array}{c}4 \\
22.2\end{array}$ & $\begin{array}{c}9 \\
50 . \\
0\end{array}$ & $\begin{array}{c}5 \\
27 . \\
8\end{array}$ & 0 & 1 & 2 & 3 & 4 & 5 & 55 & $\begin{array}{c}61 . \\
1\end{array}$ & $\begin{array}{c}3.0 \\
6\end{array}$ \\
\hline 20. & $\begin{array}{l}\text { Web } 2.0 \text { tools make } \\
\text { students to construct } \\
\text { knowledge actively. }\end{array}$ & 0 & $\begin{array}{c}17 \\
94.4\end{array}$ & $\begin{array}{c}1 \\
5.6\end{array}$ & 0 & 0 & 5 & 4 & 3 & 2 & 1 & 71 & $\begin{array}{c}78 . \\
9\end{array}$ & $\begin{array}{c}3.9 \\
4\end{array}$ \\
\hline 21. & $\begin{array}{l}\text { Web } 2.0 \text { tools } \\
\text { develop social } \\
\text { interaction of students } \\
\text { meaningfully in } \\
\text { educational contexts. }\end{array}$ & $\begin{array}{c}1 \\
5.6\end{array}$ & $\begin{array}{c}13 \\
72.2\end{array}$ & $\begin{array}{c}4 \\
22 . \\
2\end{array}$ & 0 & 0 & 5 & 4 & 3 & 2 & 1 & 69 & $\begin{array}{c}76 . \\
7\end{array}$ & $\begin{array}{c}3.8 \\
3\end{array}$ \\
\hline \multicolumn{12}{|c|}{ Mean } & $\begin{array}{r}67 \\
.5\end{array}$ & 75 & $\begin{array}{c}3.7 \\
5\end{array}$ \\
\hline
\end{tabular}

* SD: Strongly Disagree, D: Disagree, N: No Opinion, A: Agree, SA: Strongly Agree

Table 2 showed that the teachers' attitudes toward the integration of Web 2.0 tools in the classroom. One of the important things to observe was that $84.4 \%$ for the statement "I like searching the internet for teaching resources". Thus, EFL teachers liked so much towards using Web 2.0 tools and $55.6 \%$ or 10 EFL teachers agreed on item 2.: "I often use Web 2.0 tools in teaching English". It means that most of the teachers have positive attitudes toward Web 2.0 tools and using Web 2.0 tools in teaching, as supported by the distribution of responses to statements 1 to 10 . Also, as revealed by the significant distribution of responses to statement 14, most participants also believe that Web 2.0 tools can be a great supplement to support teaching English. Based on table 2 showed that answers of EFL teachers were "Agree" option. The smallest mean value of 2.33 on item 12: "I think that class time was too limited for integrating Web 2.0 tools in teaching English", and the highest was on item 1: I like to use Web 2.0 tools, and on item 5: "I like searching the internet for teaching resources", with a mean of 4.22. These findings may be interpreted to mean that the EFL teachers are generally positive about the integration of Web 2.0 tools in teaching English, the percentage was about $75 \%$ overall, although some of EFL teachers have not used them yet optimally. 


\section{EFL Teachers Responses to Integrating of Web 2.0 Tools}

To find EFL teachers' responses, the research employed interview some EFL teachers. Thus, in this case, the findings showed that there were several reasons why they used or integrated Web 2.0 tools. The teacher stated that in the interview:

Web 2.0 allows me to enrich my teaching method which I can implement in my teaching strategy. It also gives some other advantages for my teaching and learning process. By using a web 2.0 tool indirectly can reduce the distance between my students and me because the learning process can be more fun for them. And in some aspect, it suits some of the learning material perfectly.

Another teacher added:

It really supports me in the teaching and learning process at the class and was very easy to use.

Some EFL teachers give reasons to use them, they stated positively:

Easy to use and familiar.

EFL tools are more efficient to make students understand the learning material.

It is in the form of video that has visual audio. So, it makes the material lesson easy to understand.

Most EFL teachers integrated listening skills into Web 2.0 tools and a little from them integrated other language skills. This was because they thought listening skill was difficult for students to learn it. Two EFL teachers stated:

Because students sometimes have difficulty learning to listen. So, if we can use Web 2.0 tools in listening, students get more information about vocab.

Many students find it difficult to master listening skills. So, we need creative ways and media to teach and learn these skills

On the other hand, there were several challenges faced by the EFL teachers when they integrated Web 2.0 tools in teaching English at the classroom. They considered the lack of school facilities, limited access to Internet usage, limited time at class and prohibition to bring communication tools for students that restricted integration of Web 2.0 tools in the class. Two EFL teachers stated:

The tools itself, because it is prohibited for students to bring any communication tools into the class. Also, our school has no labs for a special language class. It's core

The challenge I face is nothing support from my school for the English teacher to use the Internet in the classroom because the school does not have enough financing to buy a laptop or computer and LCD.

Meanwhile, EFL teachers who did not use Web 2.0 tools in teaching English, they generally use the conventional and traditional method to teach English. Some EFL teachers stated:

In school, I still use traditional methods in teaching English where the role of teachers is more dominant in the class.

Besides, I use the traditional method, sometimes I combine with media to help students easier to learn English. 
I explain the material of the lesson that is written on the whiteboard or in the book, then give students exercise/task.

Then, all of EFL teachers revealed that integrating Web 2.0 tools in teaching English has any positive effect.

It has positive effects on students' learning. By using web 2.0, the learning process becomes more varied and not monotonous, they learn the subject more passionately. It makes students be more active and creative.

Students will get more information/knowledge independently.

Moreover, basically, EFL teachers gave comment positive about the integration of Web 2.0 tools as a medium for teaching English in the classroom activities. They stated that Web 2.0 tools supported teaching English and made an interesting class to the students when they used them. EFL teachers commented mostly:

I believe web 2.0 has the potential to provide more interesting and attractive teaching and learning process than passively receive information from the teacher or textbook all the time. But, inadequate facilities and knowledge will make it rather difficult to apply this method.

The overall results of these responses indicated that the majority of EFL teachers had positive attitudes toward the integration of Web 2.0 tools in teaching English. It was in line with the questionnaire result that relevant or linear with the interview results.

\section{DISCUSSION}

This research showed that the majority of the participating teachers believed that Web 2.0 tools helped them become more efficient in teaching English, though that Web 2.0 tools can be a great supplement to support teaching English. Thus, basically, EFL teachers agree that the integration of Web 2.0 tools in teaching English is useful for teachers and students, making classroom activities more effective and interesting and makes English easy to learn. It is suitable with a statement of Shihab (2008) that EFL teachers considered that Web 2.0 tools have the potential to improve the quality of language teaching-learning in the class. Overall, these findings may imply that the EFL teachers are generally positive towards the integration of Web 2.0 tools in teaching English at Islamic Boarding Schools and are interested to integrate computer technology resources into their teaching. The findings of this study are relevant to the results of previous studies including those conducted by Karkoulia (2016), Ozel \& Arikan (2015) and Tanfouri (2013). That means that the findings of this study increasingly strengthen the previous study of technology integration, in this case, the Web 2.0 tools in teaching English. These findings can be attributed to teachers' attitudes that like using Web 2.0 tools and most of them using them to help in teaching English as a foreign language. They respond to this technology useful for students, to motivate them and to develop their language proficiency inside the classroom (Lee, 2000 in Sulaiman, 2017). This indicates that teachers support the integration of Web 2.0 tools in teaching English at Islamic Boarding Schools. This result also demonstrated that the majority of EFL teachers use YouTube, followed by google site, blog, and wiki. This finding is in line with the results of the research conducted by Karkoulia (2016) who established that the majority of the Greek teachers in a sample of research used 


\section{Helny Mullinda*1 \& Supiani ${ }^{* 2}$ \\ INVESTIGATING THE EFL TEACHERS' ATTITUDES TOWARD THE INTEGRATION OF WEB 2.0 TOOLS IN TEACHING ENGLISH AT ISLAMIC \\ BOARDING SCHOOLS}

YouTube, followed by other Web 2.0 technologies. Some of English skills were integrated into the Web 2.0 tools to make it easy and fun to learn. With these tools, EFL teachers gain information and knowledge (Grosseck, 2009), and that encourages them to integrate the tools in their teaching.

\section{CONCLUSION}

The findings of this study showed that the majority of EFL teachers the Islamic boarding schools have positive attitudes toward the integration of Web 2.0 tools in teaching English and degree of their attitudes were high, with percentage $75 \%$. More half of the EFL teachers use Web 2.0 tools in teaching English such as YouTube, Google Sites, blogs and wikis to support teaching-learning process, to obtain information, make easy to learn and create teaching English more interesting. More of them integrated YouTube for listening skill (as many 7 EFL teachers). Nevertheless, almost half of EFL teachers also do not use Web 2.0 tools because of not provided/lack schools facilities such as having no language lab and technological equipment (computer and access Internet). The EFL teachers agree that the use of Web 2.0 tools in teaching English makes the students more motivated and interested in learning and easier to grasp the English lesson.

\section{REFERENCES}

Al-Ali, S. (2010). Understanding teachers' and students' use and attitudes of Web 2.0 in ESL classrooms at the American University of Sharjah (Doctoral dissertation).

Alhassan, R. (2017). Exploring the Relationship between Web 2.0 Tools SelfEfficacy and Teachers' Use of These Tools in Their Teaching. Journal of Education and Learning, 6(4), 217-228.

Anonymous. 2018. Descriptive Research. Retrieved on April 16, 2018, from https: //en.wikipedia.org/wiki/Descriptive_research

Başal, A., \& Aytan, T. (2014). Using Web 2.0 tools in English language teaching. In Conference proceedings. ICT for language learning (p. 372). Libreria Universitaria. it Edizioni.

Bin-Tahir, S. Z., Atmowardoyo, H., Dollah, S., \& Rinantanti, Y. (2017). Multilingual learning program: pesantren students' perceptions of the multilingual simultaneous-sequential model. JELE (Journal Of English Language and Education), 3(2), 44-53.

Bullock, D. (2004). Moving from theory to practice: An examination of the factors that preservice teachers encounter as they attempt to gain experience teaching with technology during field placement experiences. Journal of Technology and Teacher Education, 12(2), 211-237. 
Chakravarty, Srirekha. 2013. Research Methods-Survey. Retrieved on April 16, 2018, from https://cirt.gcu.edu/research/developmentresources/research_read y/descriptive/survey

Cirit, N. C. (2015). Assessing ELT Pre-Service Teachers via Web 2.0 Tools: Perceptions toward Traditional, Online and Alternative Assessment. Turkish Online Journal of Educational Technology-TOJET, 14(3), 9-19.

Crystal, D. 2001. Language and the Internet. Cambridge: Cambridge University Press

Efrizal, D. (2012). Improving students' speaking through communicative language teaching method at Mts Ja-Shaq, Sentot Ali Basa Islamic boarding school of Bengkulu, Indonesia. International Journal of Humanities and Social Science, 2(20), 127-134.

Gilakjani, A. P., \& Leong, L. M. 2012. EFL teachers' attitudes toward using computer technology in English language teaching. Theory and Practice in Language Studies, 2(3), 630-636.

Grosseck, G. (2009). To use or not to use web 2.0 in higher education?. ProcediaSocial and Behavioral Sciences, 1(1), 478-482.

Halsted, E. A. (2014). Why Padlet is an important tool for your classroom. Retrieved October 9, 2017.

Harmer, Jeremy. 2001. The Practise of English Language Teaching (3rd ed.). New York: Longman.

Hogg, M.A., \& Vaughan G.M. 2005. Introduction to Social Psychology (4th ed). Australia: Pearson Prentice Hall.

Indra, H. (2017). Salafiyah Curriculum At Islamic Boarding School in The Globalization Era. Tarbiya: Journal of Education in Muslim Society, 4(1), 7488 .

Julia, J. (2012). Potentials of Facebook as a Pedagogical Tool for College Lecturers Julia. Journal Communication Spectrum, 1(2).

Kakkar, Prakteek. 2015. Descriptive Research Design. Retrieved on April 16, 2018,from https://www.slideshare.net/Prateek301/descriptive-research-design

Karelia, Christina. 2016. Teachers' Attitudes Towards the Integration of Web 2.0 Tools in EFL Teaching. Retrieved on April 1, 2018, from http://rpltl.eap. gr/images/2016/RPLTL_7_full.pdf

Kassim H. \& Ali Z. 2007. The Use of ICT in the Implementation of StudentCentered Learning (SCL). Internet Journal of e-Language Learning \& Teaching 4/1 (2007) 15-31. 
Keleş, U. (2013). The perceptions of ELT students about the use of Web 20 tools, particularly wikis, in their future language classrooms (Doctoral dissertation, Bilkent University).

Lee, K. W. (2000). Energizing the ESL/EFL classroom through Internet activities. The Internet TESL Journal, 6(4), 1-4.

Özel, A. G., \& Arikan, A. (2015). The use of the internet and web 2.0 tools among EFL instructors. Mediterranean Journal of Humanities, 5, 313-325.

Sulaiman, Omar Ibrahim. 2017. The Attitudes of English Teachers toward Educational Technology in Teaching English and their Relation to the Degree of its Utilization in Primary Schools in the Governorate of Baghdad. (Doctoral dissertation)

Tanfouri, A. (2013). Exploring Attitudes of Teachers and Students to the Integration of Technology in EFL Classrooms (Doctoral dissertation).

Ullrich, C., Borau, K., Luo, H., Tan, X., Shen, L., \& Shen, R. (2008, April). Why web 2.0 is good for learning and for research: principles and prototypes. In Proceedings of the 17th international conference on World Wide Web (pp. 705-714). ACM.

Wang, S., \& Vásquez, C. (2012). Web 2.0 and second language learning: What does the research tell us?. CALICO Journal, 29(3), 412-430.

Warner, M., Steffen, C. and Cope, J. 2011. Raising the Bar for 21st Century Teacher Preparation. In: A. Cohan and A. Honigsfeld (eds.), Breaking the mold of preservice and in-service teacher education: Innovative and successful practices for the twenty-first century. New York: Rowman \& Littlefield 